\title{
A Fossil Wood of Dipterocarpaceae from Pliocene Deposit in the West Region of Java Island, Indonesia
}

\author{
YANCE I. MANDANG ${ }^{1}$, NORIKO KAGEMORI \\ ${ }^{1}$ Forest Product Research and Development Center, Bogor 16610, Indonesia. \\ ${ }^{2}$ Wood Research Institute, Kyoto University, Uji, Kyoto 6110011, Japan.
}

Received: 24 June 2003. Accepted: 15 December 2003

\begin{abstract}
Fossil woods in Java Island have been excavated and sold for outdoor ornaments or indoor decoration purposes since 30 years ago. These fossils are in danger of being drained out without known identities, composition and history. This study was aimed to find out the botanical identity and geographical aspect of a newly recovered silicified fossil wood from Banten area in the west region of Java Island. The fossil trunk $28 \mathrm{~m}$ in length and $105 \mathrm{~cm}$ in diameter was buried in a tuffaceous sandstone layer. The age of the stratum was thought to be Lower Pliocene. A small sample was cut from the outer part of the log and then ground to obtain thin section for anatomical observation. The main anatomical features of the fossil wood are as follows: wood diffuse porous; vessel almost exclusively solitary, vascicentric tracheid present; axial intercellular canal present, distributed in long tangential rows; fibers with distinctly bordered pit. These features show affinities of the fossil wood to the extant wood Dryobalanops of the family Dipterocarpaceae, regardless of the fact that this genus is no longer exists living in the natural forest of the present day Java Island.
\end{abstract}

(c) 2004 Jurusan Biologi FMIPA UNS Surakarta

Keywords: fossil wood, Dipterocarpaceae, Dryobalanoxylon, Pliocene, Java Island.

\section{INTRODUCTION}

Fossil woods in Java have become a commodity, excavated and sold since 30 years ago for ornamental purposes or just for collections by hobbyist. Unfortunately their origin and identity are mostly unknown so they tell nothing except their strange old appearance. It would be more meaningful if their origin, age and identity were known. Very little is known about paleo-vegetation in Java even though it has been subject of study since $19^{\text {th }}$ century.

Study on the tertiary flora in Java Island was started by Goppert in 1854, Ettingshouses in 1883 and then by Crie in 1888 (Krausel, 1925). Their study mainly was based on fossil leaves with only a few fossil woods. Goppert described 37 species in 21 genera and several families such as Palmae, Fagaceae, Moraceae, Lauraceae, Ebenaceae, Sapotaceae, Rhamnaceae, and Celasteraceae. Among Goppert's materials there were 3 specimens which-according to Krausel (1925)-belongs to

\footnotetext{
- Alamat korespondensi:

Jl. Gunung Batu 5, Bogor 16610, Indonesia, Tel. +62-251633378, +62-251-633413. Fax. +62-251-633417. e-mail: ymandang@forda.org.

2 Kyoto 6110011, Japan. Fax. 0774-38-3600. e-mail: kagemori@kuwri.kyoto-u.ac.kp
}

Dipterocarpaceae. The samples were similar to his earlier discovery, Dipterocarpoxylon javanense (Krausel, 1922b). In the same year Krausel (1922a) had also discovered several species of Dipterocarpoxylon in South Sumatra.

Crie (1888) described 9 species of plant fossils from Pliocene deposit in Gunung Kendang-Java. Two of the plant fossils belong to Dipterocarpaceae. One fossil wood sample described by Crie as Naucleoxylon spectabile (Rubiaceae), was redescribed as Dipterocarpoxylon spectabile (Dipterocarpaceae), by Krausel (1926). Krausel's findings were then criticized by Den Berger (1923, 1927). Several of Dipterocarpoxylon fossil wood described by Krausel turned out to be Dryobalanoxylon, because they have resin canals distributed in long tangential rows. Dipterocarpoxylon on the other hand, has resin canals diffusely distributed or in short tangential rows.

After Krausel's studies, Schweitzer (1958) described 1 species of Vaticoxylon, 5 species of Dipterocarpoxylon, 4 species of Dryobalanoxylon, and 2 species of Shoreoxylon from Pliocene beds in Java Island, along with other species of the same genera and family from Tertiary and Quartenary beds in Sumatra and Borneo. Many years later, unaware of the previous studies, we conducted a survey on fossil woods at fossil yards of three fossil wood collectors in 
West Java (Mandang and Martono, 1996). We found that $80 \%$ of 199 samples examined were belongs to Dipterocarpaceae. Unfortunately the origin of the sample was uncertain, and anatomical descriptions of each genus were not made. The study was based on the features that could be observed with hand lens only. So, this finding should be confirmed by further study on anatomical features of samples collected from well determined horizons.

Recently, Srivastava and Kagemori (2001) reported one other dipterocarps fossil wood, Dryobalanoxylon bogorensis, from Pliocene deposit in Leuwiliang, West Java. So up to now there are already 5 species of Dryobalanoxylon fossil wood have been found in Java. Discovery of many Dipterocarpaceae fossil woods in Java is interesting, because Dipterocarpaceae is not a dominant family in the natural forest of the present day Java Island. In this paper, we presented a detailed description of a newly discovered dipterocarps fossil wood. The occurrence and possible causes of its extinction from Java Island are discussed.

\section{MATERIAL AND METHODS}

A silicified fossil wood log sizing 28 meter in length and $105 \mathrm{~cm}$ in diameter were excavated from a rubber wood plantation near Leuwidulang village, Maja District, Lebak Prefecture, Banten Province, Java Island. The coordinate of the site is approximately SL $06^{\circ} 26^{\prime}$, EL 106 $23^{\prime}$ (Fig. 1). According to the geology map composed by Rusmana et al. (1991), the site is situated in Genteng Formation. The age of the formation was thought to be lower Pliocene (van Bemmelen, 1949). The fossil wood was buried in a rather soft; fine grained, grayish color tuffaceous sandstone. It was broken into 15 pieces about $2 \mathrm{~m}$ each after the silification process occurred, and apparently no further silification occurred thereafter. There is no deposition of new silica layer in the transverse faces of the broken logs, as have been seen in some other fossil wood.

A piece of sample was taken from the outer part of the log and then cut and ground to obtain thin sections of transverse, radial, and tangential face. Observation and description follow the format of the IAWA List of Microscopic Features suitable for hardwood identification (Wheeler et al. 1989). Vessel length was measured from tip to tip. Ray height was also measured from tip to tip, the total height of multiseriate and uniseriate portions. Number of observation for each quantitative character also follows the list as long as permissible by the available slide. For each quantitative character, mean value and standard error of the mean are given.

The results of observation were compared with the description of extant wood described by Desch (1941), Chu (1974), and llic (1995). Samples of extant wood in the xylarium of the Forest Products Research
Institute in Bogor, Indonesia, were also used for comparison. Comparisons were also made with other fossil wood of the same genus from Sumatra, Borneo, and Java (Krausel, 1922a; Krausel, 1922b; Krausel, 1926; Den Berger 1923, 1927; Schweitzer, 1958, Srivastava and Kagemori, 2001).

\section{RESULT AND DISCUSSION}

\section{Systematic \\ Sub Class : Dicotyledons \\ Family : Dipterocarpaceae \\ Genus : Dryobalanoxylon Den Berger, 1923 \\ Species : Dryobalanoxylon lunaris Y. Mandang and N. Kagemori sp. nov. (Fig. 3-8).}

\section{Diagnostic features:}

Wood diffuse porous, vessel almost exclusively solitary, vascicentric tracheid present; axial resin canals present, distributed in concentric rows; fibers with distinctly bordered pit; ray exceeds $2000 \mu \mathrm{m}$ tall, prismatic crystal present in enlarged parenchyma cells.

\section{Description:}

Wood: diffuse porous.

Growth ring: regularly spaced parenchyma bands containing concentric rows of axial resin canal resemble growth ring boundaries.

Vessel: evenly distributed, almost exclusively solitary $(92 \%)$, a few in radial or oblique pairs; tangential diameter 195-257 $\mu \mathrm{m}$, average $22 \pm 10 \mu \mathrm{m}$; radial diameter 217-339 $\mu \mathrm{m}$, average $274 \pm 12 \mu \mathrm{m}$; frequency $5-8$ per $\mathrm{mm}^{2}$, average $6 \pm 0.6$ per $\mathrm{mm}^{2}$; length $440-970 \mu \mathrm{m}$, average $751 \pm 46 \mu \mathrm{m}$; end wall horizontal to slightly oblique; intervessel pit not observed; vessel ray pit not observed; perforation plate simple; tyloses common; deposit not observed.

Vascicentric tracheid: present, with 2-3 rows of bordered pit.

Parenchyma: both paratracheal and apotracheal: paratracheal vascicentric, tendency to aliform with narrow and short to long wing; apotracheal mainly in regularly spaced concentric bands encircling axial resin canals, a few diffuse in aggregates forming short tangential lines between the rays.

Rays: heterocellular with 1-4 rows of upright cells; 1-4 seriate, mostly 3-4 seriate; up to $2980 \mu \mathrm{m}$ tall, average $1405 \pm 567 \mu \mathrm{m}$ (range $5-90$ cells high, commonly $30-60$ cells high); frequency $5-7$, average $5.8 \pm 0.6$ per tangential $\mathrm{mm}$; tend to be storied in some places; occasionally 2 or 3 rays are longitudinally connected.

Fiber: very thick walled, with distinctly bordered pits.

Intercellular canal: axial resin canal present, distributed in concentric rows, some definitely not full circle; almost regularly spaced and the distance between rows are $0.5 \mathrm{~mm}$ to $2 \mathrm{~mm}$; tangential diameter 91-242 $\mu \mathrm{m}$, average $129 \pm 17 \mu \mathrm{m}$ : other 
canals are diffuse as single canals among the axial Similarities to extant woods

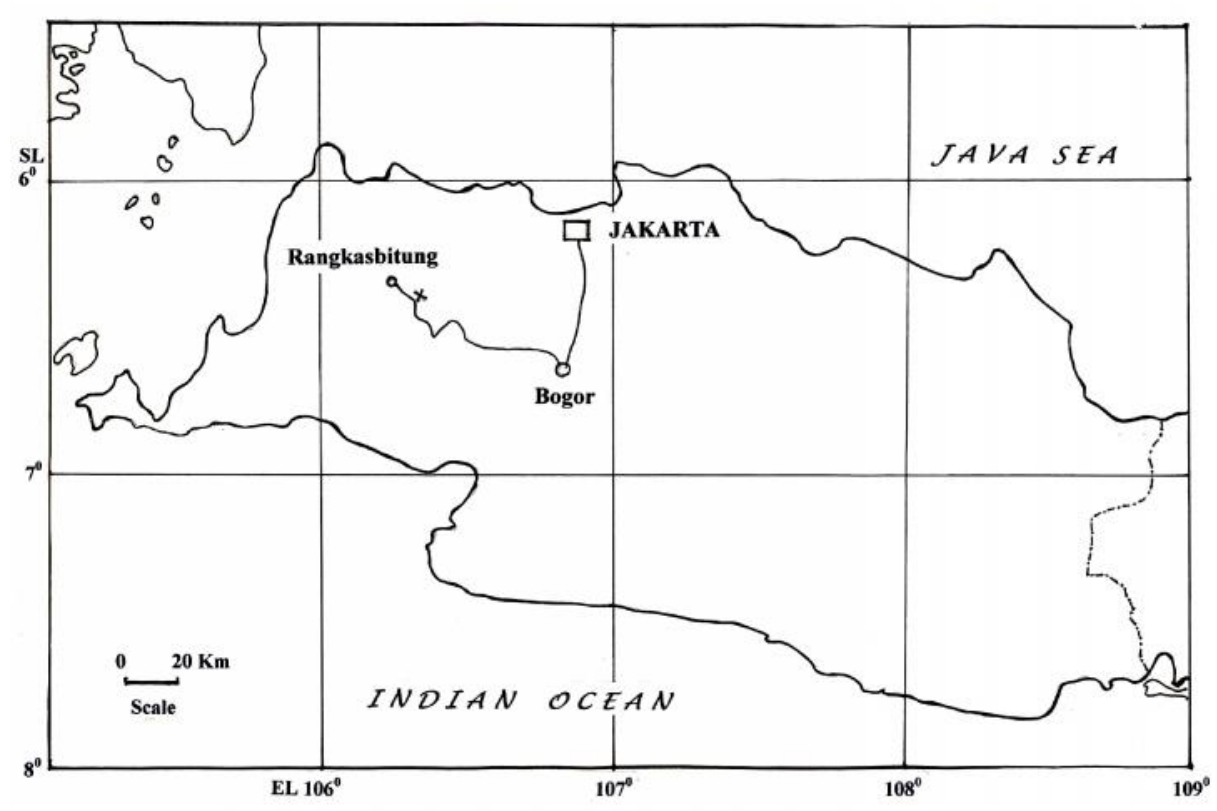

Figure 1. Map of West Java showing the site of fossil wood under study (x).

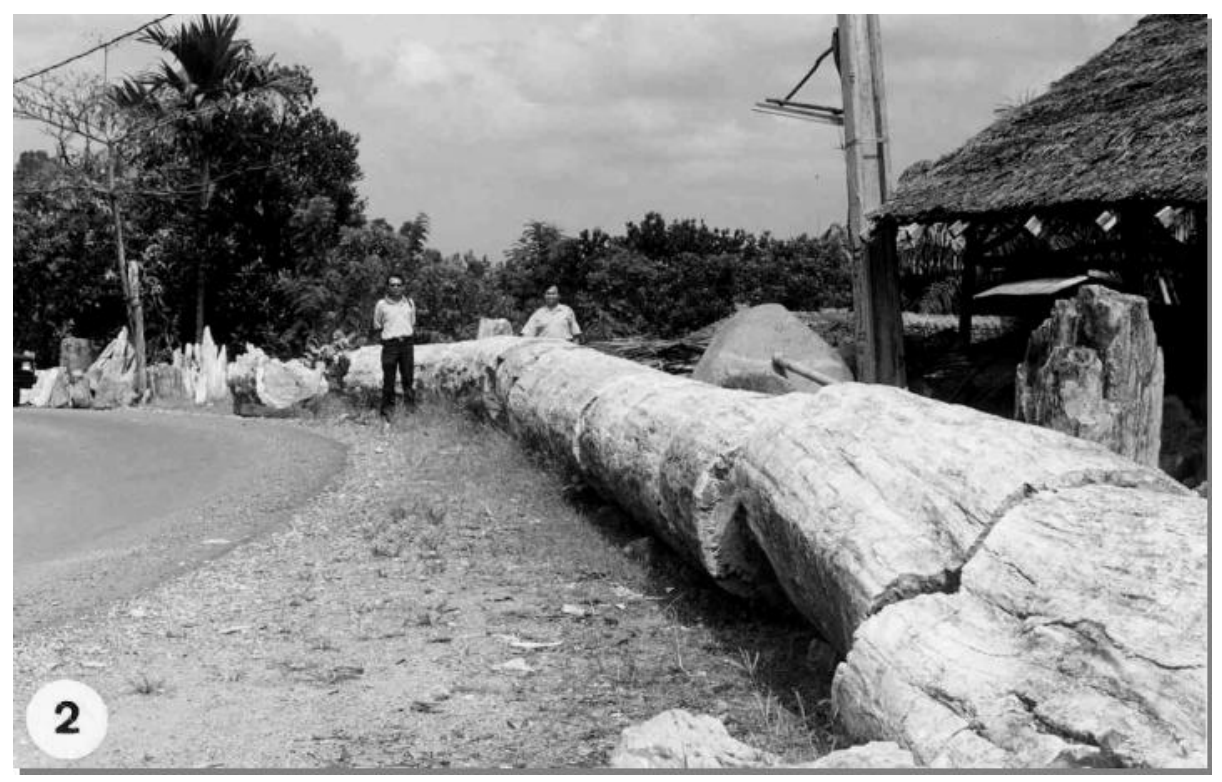

Figure 2. The fossil wood Dryobalanoxylon after being excavated near Rangkasbitung.

elements.

Mineral inclusion: prismatic crystals present in the enlarged parenchyma cells.

Holotype: BF 93, Forest Products Research Institute, Bogor, Indonesia.

Size: length, $28 \mathrm{~m}$; diameter at breast height, $105 \mathrm{~cm}$.

Origin: Leuwidulang, Banten, West Java.

Horizon: Genteng Formation

Age: Lower Pliocene

Repository: Forestry Museum Jakarta, Indonesia
The combinations of diffuse porous and the occurrence of vascicentric tracheids and axial resin canal are characteristics of Dipterocarpaceae family. Vessels almost exclusively solitary, resin canal distributed in long concentric lines and fibers with distinctly bordered pit indicated that the Leuwidulang fossil wood, Dryobalanoxylon lunaris, is closely related to modern Dryobalanops Gaertner f. (Table 1.). Dryobalanoxylon lunaris differs from modern Dryobalanops wood mainly in ray height and in size of resin canals. It has much taller rays and has much bigger resin canal.

Dryobalanoxylon lunaris has resin canals distributed in closely spaced tangential rows resembling growth ring boundaries. Among modern Dryobalanops, only Dryobalanops fusca has the same distribution of resin canal as in Dryobalanoxylon lunaris. However Dryobalanops fusca has much shorter and narrower rays. Furthermore, the diameter of resin canal in modern Dryobalanops woods is less than $100 \mu \mathrm{m}$ (llic, 1994).

There should be silica bodies inside the ray cells of Dryobalanoxylon as in modern Dryobalanops but it might have been dissolved during silification. The occurrence of silica bodies in ray cells is useful in differentiating modern Dryobalanops from Shorea (sections Rubroshorea and Richetia), Parashorea, and Hopea. It seems impossible however to use this feature for differentiation of sillicified fossil woods, so we have to rely on other features.

\section{Comparison with other fossil wood}

Seventeen species of Dryobalanoxylon fossil woods have been found, of which 3 were found in India, 1 in Cambodia, 1 in Vietnam, and 11 species in Indonesia (Table 2: Schweitzer 1958; Srivastava et al, 
2001). Anatomical features of Dryobalanoxylon from compared to the recently recovered fossil wood from Indonesia are summarized in Table 3, 4 and 5, Leuwidulang, Dryobalanoxylon lunaris.
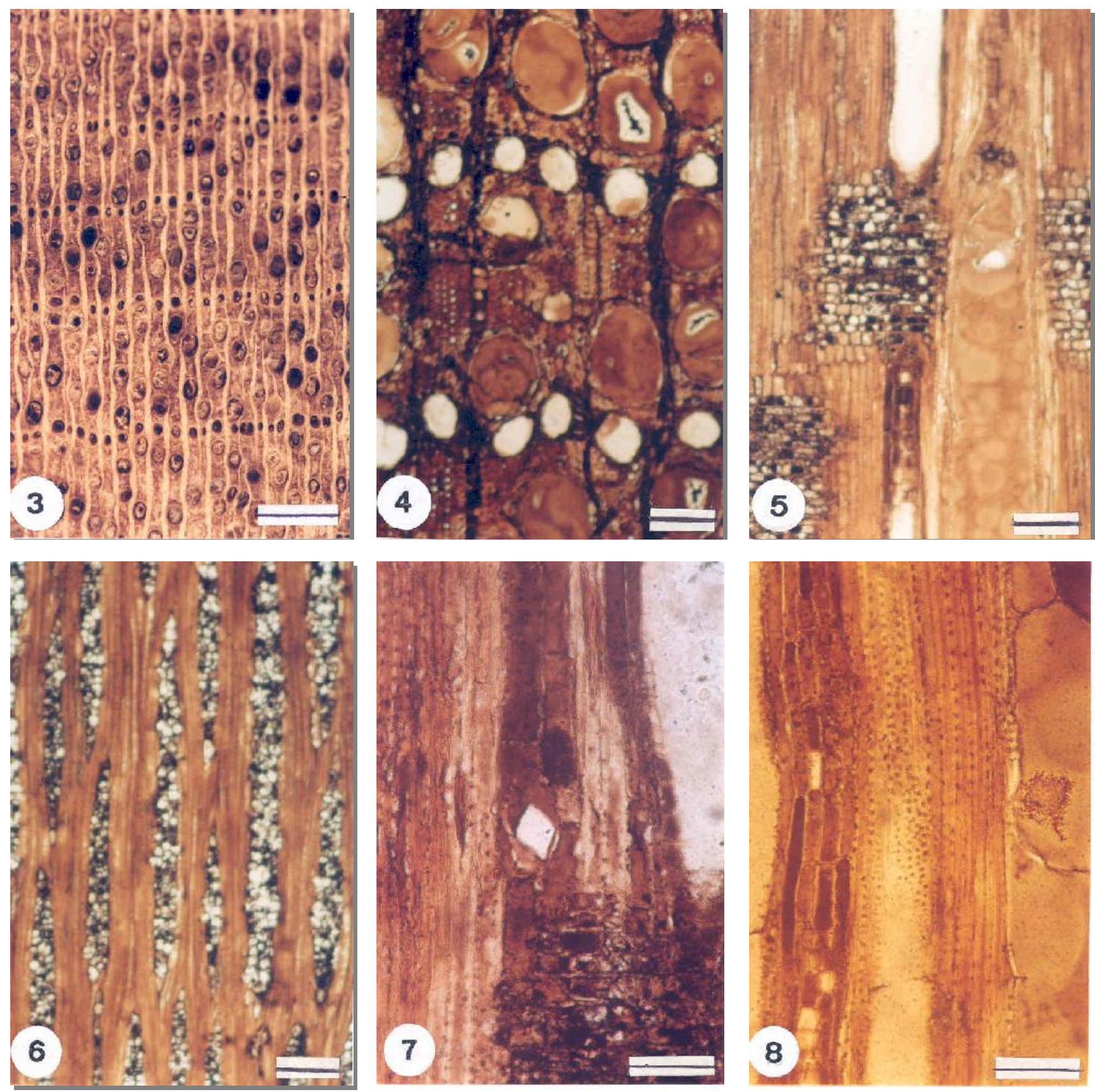

Figure 3-8. Dryobalanoxylon lunaris: (3) transverse surface (scale bar $=1 \mathrm{~mm}$ ); (4) transverse surface (scale bar $=200$ $\mu \mathrm{m}$ ); (5) radial surface (scale bar $=200 \mu \mathrm{m})$; (6) tangential surface (scale bar $=200 \mu \mathrm{m}$ ); (7) radial surface, showing crystal in enlarged parenchyma cell (scale bar $=100 \mu \mathrm{m}) ; 8)$ radial surface, showing vascicentric tracheids $(\mathrm{scale}$ bar $=100 \mu \mathrm{m})$.

Dryobalanoxylon lunaris differs from the other Dryobalanoxylon fossil wood mainly in vessel length and in mineral inclusions. $D$. lunaris has much longer vessel elements and has crystal inclusions in the enlarged parenchyma cells. $D$. lunaris also differs from most of the other Dryobalanoxylon fossil woods in ray height. $D$. lunaris has rays up to 90 cells high, the same with Dryobalanoxylon sumatrensis.
However $D$. sumatrensis has much shorter vessel elements, and has no crystals in its parenchyma.

\section{Phytogeography}

Dipterocarpaceae in natural forest of the present day Java Island represented only by 5 genera i.e. Anisoptera, Dipterocarpus, Hopea, Shorea (Anthoshorea) and Vatica (Prawira, 1976). Their occurrences are so rare and therefore they are not 
considered as economically important trees in the area. There are no records of Dryobalanops

Table 1. Comparison between Dryobalanoxylon lunaris fosil wood and Dryobalanops wood.

\begin{tabular}{|c|c|c|c|c|}
\hline \multirow{2}{*}{$\begin{array}{l}\text { Anatomical } \\
\text { features }\end{array}$} & \multicolumn{3}{|c|}{ Dryobalanops Gaertner f. } & \multirow{2}{*}{$\begin{array}{c}\text { Dryobala } \\
\text { noxylon } \\
\text { lunaris }\end{array}$} \\
\hline & Desch, 1941 & Chu, 1974 & Ilic, 1994 & \\
\hline \multicolumn{5}{|l|}{ Wood } \\
\hline Diffuse porous & + & + & + & + \\
\hline $\begin{array}{l}\text { Growth ring } \\
\text { boundaries } \\
\text { Vessel }\end{array}$ & $\begin{array}{l}+ \\
\text { resembling }\end{array}$ & . & - & $\stackrel{+}{+} \underset{\text { resembling }}{ }$ \\
\hline Mostly solitary & + & $\stackrel{+}{89-95 \%}$ & $\stackrel{+}{90-95 \%}$ & $\begin{array}{l}+ \\
(92 \%)\end{array}$ \\
\hline $\begin{array}{l}\text { Tangential diameter } \\
(\mu \mathrm{m})\end{array}$ & $\begin{array}{l}182 \text { (D.a.); } \\
181 \text { (D.o.) }\end{array}$ & $180-232$ & $\begin{array}{l}130-240 \\
(160-220)\end{array}$ & $\begin{array}{l}190-257 \\
\bar{a}=228\end{array}$ \\
\hline Frequency $/ \mathrm{mm}^{2}$ & $\begin{array}{l}8.9 \text { (D.a.) } \\
7.7 \text { (D.o.) }\end{array}$ & . & $\begin{array}{l}5(8-12) 17 \\
5(\text { D.f. }) \\
17 \text { (D.r.) }\end{array}$ & $\begin{array}{l}6-8 \\
\bar{a}=6.5\end{array}$ \\
\hline Length $(\mu \mathrm{m})$ & . & . & $\cdot$ & $\begin{array}{l}440-970 \\
\bar{a}=751\end{array}$ \\
\hline $\begin{array}{l}\text { Tyloses } \\
\text { Vascicentric tracheid }\end{array}$ & + & + & + & + \\
\hline $\begin{array}{l}\text { Presence } \\
\text { Parenchyma }\end{array}$ & + & + & + & + \\
\hline Diffuse in aggregates & + & + & + & + \\
\hline $\begin{array}{l}\text { Vascicentric, } \\
\text { incomplete }\end{array}$ & + & + & + & + \\
\hline Aliform & tendency & + & tendency & tendency \\
\hline Confluent & . & $(+)$ & . & . \\
\hline $\begin{array}{l}\text { Banded } \\
\text { Ray }\end{array}$ & + & + & + & + \\
\hline Heterocellular & + & + & + & + \\
\hline Marginal cells & . & $1-3$ & $1-3$ & $1-4$ \\
\hline Sheath cells & . & $(+)$ & $(+)$ & $(+)$ \\
\hline Width, seriate & . & $1-6$ & $1-3-6$ & $1-4(3-4)$ \\
\hline Height, cells & . & . & . & $\begin{array}{l}5-90 \\
(30-60)\end{array}$ \\
\hline Height $(\mu \mathrm{m})$ & . & $<2000$ & up to 1000 & $\begin{array}{l}744-2900 \\
\bar{a}=1405\end{array}$ \\
\hline Frequency per mm & . & . & $4-6(8)$ & $5-7$ \\
\hline Storied structure & $\begin{array}{l}\text { usually in } \\
\text { D.a. }\end{array}$ & $\begin{array}{l}\text { tendency } \\
\text { except in } \\
\text { D.r. }\end{array}$ & $\cdot$ & tendency \\
\hline \multicolumn{5}{|l|}{ Fiber } \\
\hline Distinctly bordered pit & . & + & $(+)$ & + \\
\hline Wall thickness & . & $\cdot$ & $\begin{array}{l}\text { moderately } \\
\text { thick to thick }\end{array}$ & thick \\
\hline \multicolumn{5}{|l|}{ Resin canal, axial } \\
\hline Diffuse & . & . & . & + \\
\hline Long tangential rows & + & + & + & + \\
\hline Diameter $(\mu \mathrm{m})$ & $<$ vessel & $<$ vessel & $40-70$ & $\begin{array}{l}91-242 \\
\bar{a}=129\end{array}$ \\
\hline \multicolumn{5}{|l|}{ Mineral inclusion } \\
\hline Silica in ray cells & + & + & + & $?$ \\
\hline Silica in parenchyma & $\cdot$ & $\cdot$ & $\begin{array}{l}\text { sparse in } \\
\text { D.b. \& D.o. }\end{array}$ & . \\
\hline $\begin{array}{l}\text { Crystals in } \\
\text { parenchyma }\end{array}$ & $\stackrel{+}{(D .0 .)}$ & $\begin{array}{l}(+) \\
\text { D.f. \& D.r. }\end{array}$ & $\begin{array}{l}(+) \\
\text { D.k., D.I. } \\
\text { D.o., D.r. }\end{array}$ & + \\
\hline
\end{tabular}

Legend: D.a.= Dryobalanops aromatica; D.b. = Dryobalanops beccarii; D.f. = Driobalanops fusca; D.k. = D. keithii; D.I. = Dryobalanops lanceolata; D.o. $=$ Dryobalanops oblongifolia; D.r. $=$ Dryobalanops rappa; $\bar{a}=$ mean value; + (present); - absent; (+) some conform; . data not available; < less than. occurrence in Java Island except those recently planted in arboretum and experimental forest using seed brought from other islands.

In a recent survey in Leuweng Sancang Nature Reserve situated about $250 \mathrm{~km}$ south east of Jakarta, Sidiyasa (1985) found only 3 genera and 4 species of Dipterocarpaceae, these are Dipterocarpus gracilis, Dipterocarpus hasseltii, Shorea javanica and Anisoptera costata. In Yanlapa Nature Reserve, which is only about $10 \mathrm{~km}$ east of Leuwidulang village, the site of fossil wood being studied, Sutisna (1995) recorded only one species of Dipterocarpaceae that is Dipterocarpus hasselti. It was dominant only in 3 out of 12 plots surveyed. Jafarsidik and Anwar (1987) did not find any dipterocarps trees in Kali Bedahan mangrove forest, in seashore about $180 \mathrm{~km}$ east of Jakarta. Yamada (1975) also did not find dipterocarps trees in montane forest of Mt. Pangrango, about $100 \mathrm{~km}$ south of Jakarta.

The genus Dryobalanops now occurs only in Sumatra Island, Borneo Island and Peninsular Malaysia. There are two species of Dryobalanops in Sumatra and Peninsular Malaya: Dryobalanops sumatrensis Kosterm. (Syn. D. aromatica Gaertner f.) and $D$. oblongifolia Dyer. In Sumatra Dryobalanops occurs in most of the provinces except in Lampung and Bengkulu, the two provinces in the south part of the island. Genus Dryobalanops in Borneo Island consists of eight species that are $D$. sumatrensis Kosterm., $D$. beccarii Dyer, D. fusca V.Sl., D. keithii Sym., D. lanceolata Burck., D. oblongifolia Dyer and $D$. rappa Becc., and D. oocarpa V.SI.

The discovery of Dryobalanoxylon fossil wood in this study conform to the previous observation conducted by Krausel (1922a, 1922b, 1926), den Berger (1923, 1927), Schweitzer (1958), Mandang and Martono (1996), and Srivastava and Kagemori (2001). The absence of extant wood in the present day natural forest of Java indicated that it must have extinct by some reasons. According to Endert (Steenis, 1963) the absence of several Sunda shelf elements in Java were due to serious effect of volcanic 
activities in the Tertiary, and then destruction by agricultural practice. These reasons however did not

Table 2. List of Dryobalanoxylon fossil woods in Indonesia.

\begin{tabular}{|c|c|c|c|c|}
\hline No. & Species & Origin & Age & Authors \\
\hline 1 & D. javanense & $\begin{array}{l}\text { Bolang, West } \\
\text { Java } \\
\text { Tenjo, West } \\
\text { Java }\end{array}$ & $\begin{array}{l}\text { Tertiary } \\
\text { Pliocene }\end{array}$ & $\begin{array}{l}\text { Krausel, } 1922 \\
\text { Den Berger, } 1923 \\
\text { Schweitzer, } 1958\end{array}$ \\
\hline 2 & D. spectabile & $\begin{array}{l}\text { Bogor, West } \\
\text { Java } \\
\text { Banten }\end{array}$ & $\begin{array}{l}\text { Pliocene } \\
\text { Pliocene }\end{array}$ & $\begin{array}{l}\text { Krausel, } 1926 \\
\text { Den Berger, } 1927 \\
\text { Schweitzer. } 1958\end{array}$ \\
\hline 3 & D. tobleri & $\begin{array}{l}\text { Palembang, } \\
\text { South Sumatra } \\
\text { Banten, West } \\
\text { Java }\end{array}$ & $\begin{array}{l}\text { Tertiary } \\
\text { Pliocene }\end{array}$ & $\begin{array}{l}\text { Krausel, } 1922 \\
\text { Den Berger, } 1923 \\
\text { Schweitzer, } 1958\end{array}$ \\
\hline 4 & D. rotundatum & Jambi, Sumatra & Quaternary & Schweitzer, 1958 \\
\hline 5 & D. musperi & $\begin{array}{l}\text { Bogor, West } \\
\text { Java }\end{array}$ & Pliocene & Schweitzer, 1958 \\
\hline 6 & D. mirabile & Jambi, Sumatra & Quarternary & $\begin{array}{l}\text { Schweitzer, } 1958 \\
\text { Schweitzer, } 1958\end{array}$ \\
\hline 7 & D. neglectum & $\begin{array}{l}\text { Jambi, Sumatra } \\
\text { ? Bogor, } \\
\text { West Java }\end{array}$ & $\begin{array}{l}\text { Quarternary } \\
?\end{array}$ & $\begin{array}{l}\text { Schweitzer, } 1958 \\
\text { Schweitzer, } 1958\end{array}$ \\
\hline 8 & D. bangkoense & $\begin{array}{l}\text { Jambi, Sumatra } \\
\text { Banten, West } \\
\text { Java }\end{array}$ & $\begin{array}{l}\text { Quarternary } \\
\text { Pliocene } \\
\text { Miocene }\end{array}$ & Schweitzer, 1958 \\
\hline 9 & D. borneense & East Kalimantan & Miocene & Schweitzer, 1958 \\
\hline 10 & D. sumatrense & Jambi, Sumatra & Pliocene & Schweitzer, 1958 \\
\hline 11 & D. bogorensis & $\begin{array}{l}\text { Leuwiliang, } \\
\text { West Java }\end{array}$ & Pliocene & $\begin{array}{l}\text { Srivastava \& } \\
\text { Kagemori, } 2001\end{array}$ \\
\hline 12 & D. lunaris & $\begin{array}{l}\text { Leuwidulang, } \\
\text { Banten, West } \\
\text { Java }\end{array}$ & Pliocene & This report \\
\hline
\end{tabular}

Table 3. Comparison between Dryobalanoxylon lunaris and other Dryobalanoxylon fossil wood species: vessel features [Krausel, 1922b; Krausel, 1926; Schweitzer, 1958; Srivastava \& Kagemori, 2001 (except for D. lunaris)].

\begin{tabular}{|c|c|c|c|c|c|}
\hline \multirow{2}{*}{\multicolumn{2}{|c|}{ Fossil species }} & \multicolumn{4}{|c|}{ Vessel features } \\
\hline & & $\begin{array}{l}\text { Frequency } \\
\text { per } \mathrm{mm}^{2}\end{array}$ & $\begin{array}{c}\text { Tangential } \\
\text { diameter }\end{array}$ & $\begin{array}{c}\begin{array}{c}\text { Radial } \\
\text { diameter }\end{array} \\
\mu \mathrm{m}\end{array}$ & $\begin{array}{l}\text { Vessel } \\
\text { length }\end{array}$ \\
\hline \multirow[t]{2}{*}{ D. javanense } & $a$ & $8-16$ & $70-210$ & $65-275$ & \\
\hline & $b$ & $5-10$ & $125-225$ & $\begin{array}{l}125-275 \\
(250)\end{array}$ & $250-500$ \\
\hline \multirow[t]{2}{*}{ D. spectabile } & a & $10-16$ & $95-170$ & $130-270$ & $400-700$ \\
\hline & $b$ & $9-14$ & $95-200$ & $\begin{array}{l}125-275 \\
(200-250)\end{array}$ & 500 \\
\hline \multirow[t]{2}{*}{ D. tobleri } & a & $8-16(12-16)$ & $80-230$ & $100-330$ & $250-550$ \\
\hline & $b$ & $5-12$ & $150-200$ & $175-350$ & 250 \\
\hline D. rotundatum & & $10-16(14)$ & $50-300$ & & $250-500$ \\
\hline \multirow{2}{*}{\multicolumn{2}{|c|}{ D. musperi }} & $15-22$ & \multicolumn{2}{|c|}{$60-150(100-125)$} & . \\
\hline & & $10-15$ & \multicolumn{2}{|c|}{$60-200(150-200)$} & \\
\hline \multicolumn{2}{|l|}{ D. mirabile } & $9-22$ & $75-175$ & $100-275$ & $150-500$ \\
\hline \multirow{2}{*}{\multicolumn{2}{|c|}{$\begin{array}{l}\text { D. neglectum } \\
\text { D. bangkoense }\end{array}$}} & $7-13$ & $150-225$ & $225-300$ & $300-500$ \\
\hline & & $7-13$ & $75-225$ & $\begin{array}{l}125-325 \\
(250-275)\end{array}$ & $100-600$ \\
\hline \multirow{5}{*}{\multicolumn{2}{|c|}{$\begin{array}{l}\text { D. borneense } \\
D . \text { sumatrense } \\
D . \text { bogorensis } \\
D . \text { lunaris }\end{array}$}} & $10-16$ & $60-125$ & $100-200$ & $250-600$ \\
\hline & & $4-8$ & $75-200$ & $125-325$ & $200-700$ \\
\hline & & $3-4$ & $120-286$ & $165-336$ & $308-572$ \\
\hline & & $5-8$ & $195-257$ & $217-339$ & $440-970$ \\
\hline & & $\overline{\mathrm{a}}=6.5$ & $\overline{\mathrm{a}}=228$ & $\bar{a}=274$ & $\bar{a}=751$ \\
\hline
\end{tabular}

Legend: ( ) common value; ā : average; . data not available had a tentative idea that for a long time in the Tertiary, Java was consisted of islands arc which similar to that of the present Lesser Sunda Island.

The last explanation by Endert was not satisfactory because, eventhough agricultural practices might be significant in reducing the population of some elements in Java Island but it was unlikely the main cause of extinction of Dryobalanops. The fact is that Dryobalanops also does not occur in Lampung and Bengkulu, the two provinces in the southern part of Sumatra Island, where agricultural practices have not been as intensive as in Java. Furthermore, there are still considerable amounts of natural forest in these two provinces but still, Dryobalanops also does not occur there. So the cause of Dryobalanops extinction from Java and southern part of Sumatra was most likely by volcanic activities, which was occurred somewhere around the present day Sunda strait. Dryobalanops was obviously not able to withstand the continuous shower of volcanic ash. Dryobalanops is very sensitive as shown by formation of resin canals. Disturbance from outside of the plant stimulate the formation of resin canals in wood, which are mostly distributed in concentric lines. Continuous and heavy disturbance in wide areas must have caused mass extinction of Dryobalanops from West Java and southern part of Sumatra.

The results of the present study, together with the early discovery on the abundance of Dipterocarpaceae fossil wood in the west region of Java, are indicative that this part of the island was connected by land to Sumatra and Borneo and Asia's main land once upon a time during the Tertiary period. Many plants from Asia must have been migrated through this land connection to Java even though some of them were then destroyed and extinct. The inability of Dryobalanops and other extinct genera to remigrate from upper part of Sumatra and Borneo in the later period might had been hampered among others by separation of these islands by sea water, as has been occurred at the end of Pleistocene epoch. 
Table 4. Comparison between Dryobalanoxylon lunaris and other Dryobalanoxylon fossil wood: ray features [Krausel, 1922b; 1926; Schweitzer, 1958; Srivastava and Kagemori, 2001 (except for D. lunaris)].

\begin{tabular}{|c|c|c|c|c|c|c|c|}
\hline \multirow{2}{*}{$\begin{array}{l}\text { Fossil } \\
\text { species }\end{array}$} & \multirow{2}{*}{$\begin{array}{l}\text { Ray } \\
\text { width } \\
\text { (cells) }\end{array}$} & \multicolumn{2}{|c|}{$\begin{array}{l}\text { Ray height } \\
\text { (cells) }\end{array}$} & \multirow{2}{*}{$\begin{array}{c}\text { Ray } \\
\text { height } \\
(\mu \mathrm{m})\end{array}$} & \multirow{2}{*}{$\begin{array}{c}\text { Ray } \\
\text { distance } \\
\text { (cells) }\end{array}$} & \multirow{2}{*}{$\begin{array}{l}\text { Sheath } \\
\text { cells }\end{array}$} & \multirow{2}{*}{$\begin{array}{l}\text { Storried } \\
\text { structure }\end{array}$} \\
\hline & & $\begin{array}{l}\text { Multi } \\
\text { seriate }\end{array}$ & $\begin{array}{l}\text { Unise- } \\
\text { riate }\end{array}$ & & & & \\
\hline \multirow[t]{2}{*}{ D. javanense } & $\begin{array}{c}1-6 \\
(3-5)\end{array}$ & $3-30$ & . & . & & & . \\
\hline & $\begin{array}{c}1-6 \\
(3-5)\end{array}$ & $\begin{array}{l}3-45 \\
(30)\end{array}$ & . & . & $2-19$ & + & . \\
\hline \multirow[t]{2}{*}{ D. spectabile } & $\begin{array}{c}1-6 \\
(3-6)\end{array}$ & $3-30$ & . & . & & & . \\
\hline & $\begin{array}{l}1-4 \\
(3)\end{array}$ & 3-35 & $\begin{array}{l}\text { up to } \\
15\end{array}$ & . & 4-12 & + & . \\
\hline \multirow[t]{2}{*}{ D. tobleri } & $\begin{array}{c}1-6 \\
(2-4)\end{array}$ & $10-50$ & . & . & & & . \\
\hline & $\begin{array}{c}1-5 \\
(2-4)\end{array}$ & $35-50$ & . & . & $6-8$ & + & . \\
\hline D. rotundatum & $\begin{array}{c}1-4 \\
(2-3)\end{array}$ & $\begin{array}{c}2-30 \\
(18-22)\end{array}$ & $\begin{array}{c}\text { up to } \\
15\end{array}$ & . & $2-20$ & - & + \\
\hline D. musperi & $\begin{array}{c}1-4 \\
(2-3)\end{array}$ & $\begin{array}{c}20-35 \\
(20-25)\end{array}$ & $\begin{array}{l}\text { up to } \\
20\end{array}$ & . & $1-12$ & . & . \\
\hline D. mirabile & $\begin{array}{c}1-5 \\
(3-4)\end{array}$ & $20-30$ & . & . & $2-12$ & - & . \\
\hline D. neglectum & $1-3$ & 56 & . & . & $4-18$ & . & . \\
\hline D. bangkoense & $\begin{array}{c}1-5 \\
(3-4)\end{array}$ & $\begin{array}{c}4-70 \\
(25-40)\end{array}$ & $\begin{array}{l}\text { up to } \\
15\end{array}$ & . & $2-23$ & . & . \\
\hline D. borneense & $1-3$ & 55 & . & . & $3-9$ & + & . \\
\hline D. sumatrense & $1-5$ & $4-90$ & $\begin{array}{l}\text { up to } \\
15\end{array}$ & . & $2-15$ & - & . \\
\hline D. bogorensis & $1-6$ & $11-36$ & . & $\begin{array}{l}500- \\
1200\end{array}$ & . & & . \\
\hline D. Iunaris & $\begin{array}{c}1-4 \\
(3-4)\end{array}$ & $\begin{array}{c}5-90 \\
(30-60)\end{array}$ & $\begin{array}{l}\text { up to } \\
20\end{array}$ & $\begin{array}{c}744- \\
2900 \\
\bar{a}= \\
1405\end{array}$ & . & - & tendency \\
\hline
\end{tabular}

Legend: ( ) common value; + present; - absent; . data not available

Table 5. Mineral inclusions and resin canal in Dryobala-noxylon fossil wood [Krausel, 1922b; 1926; Schweitzer, 1958; Srivastava and Kagemori, 2001 (except for D. lunaris)].

\begin{tabular}{|c|c|c|c|c|}
\hline \multirow[b]{2}{*}{ Fossil species } & \multicolumn{2}{|c|}{ Crystal } & \multirow{2}{*}{$\begin{array}{c}\text { Silica } \\
\text { particles } \\
\text { in ray }\end{array}$} & \multirow{2}{*}{$\begin{array}{c}\text { Resin canal } \\
\text { diameter } \\
\text { um }\end{array}$} \\
\hline & In ray & $\begin{array}{l}\text { In paren- } \\
\text { chyma }\end{array}$ & & \\
\hline \multirow[t]{2}{*}{ D. javanense } & . & . & & $30-80$ \\
\hline & $+?$ & . & $+?$ & $30-100$ \\
\hline \multirow[t]{2}{*}{ D. spectabile } & . & . & & $30-120$ \\
\hline & & & + & $40-100$ \\
\hline \multirow[t]{2}{*}{ D. tobleri } & $+?$ & . & & $50-250$ \\
\hline & . & & & $50-100$ \\
\hline D. rotundatum & . & . & & $50-100$ \\
\hline D. musperi & + & . & & $40-75$ \\
\hline D. mirabile & + & . & $+?$ & $60-200$ \\
\hline D. neglectum & + & . & & $40-150$ \\
\hline D. bangkoense & $+?$ & . & $+?$ & $25-125$ \\
\hline D. borneense & . & . & . & $40-70$ \\
\hline D. sumatrense & + & . & $+?$ & $75-110$ \\
\hline D. bogorensis & - & - & - & $33-100$ \\
\hline$D$. Iunaris & - & + & . & $91-242$ \\
\hline
\end{tabular}

Legend: + present; - absent; +? questionable; . not mentioned.

\section{CONCLUSION}

The silicified fossil wood log excavated from Pliocene deposit near Leuwidulang village in Banten, Java Island, belongs to Dipterocarpaceae family. Anatomical features of the fossil wood showed that the fossil wood belongs to genus Dryobalanoxylon Den Berger. However, the fossil wood differs from the previously described Dryobalanoxylon fossil woods species in vessel length, ray height and crystals inclusion in the enlarged parenchyma cells, so it is unlikely that this specimen belong to any of them. It should therefore be assigned to another species, as we proposed Dryobalanoxylon lunaris.

The extant genus Dryobalanops Gaertner f. is now existing only in Sumatra, Borneo and Malay Peninsula. The occurrence of Dryobalanoxylon fossil wood in Java indicates that the ancestor of Dryobalanops was distributed in wider areas. Its extinction from Java was thought to be by volcanic activities. The inability of Dryobalanops to remigrate from Sumatra and Borneo in the later period might have been hampered by separation of these islands by seawater.

\section{ACKNOWLEDGEMENT}

The authors wish to express their sincere gratitude to Professor Shuichi Kawai of Kyoto University for his encouragement and support. We wish also to thank Dr. Kazuo Terada of Fukui Dinosaur Museum Japan for his invaluable help and suggestions.

\section{REFERENCES}

Bemmelen, R.W. van. 1949. The Geology of Indonesia, Vol. IA. The Hague: Martinus Nijhoff.

Chu, Fei Tan F. 1974. Anatomical features of Dipterocarp timbers of Sarawak. Garden's Bulletin Singapore 27: 95-199.

Crie, M.L. 1888. Recherches sur la Flore Pliocenee de Java. Samlung des Geologishen Reichsmuseums in Leiden. Beitrage zur Geologie von Ost-Asians Australlians 5: 1-21 $+8 \mathrm{Tab}$.

Den Berger, L.G. 1923. Fossile houtsoorten uit het Tertiar van Zuid-Sumatra. Verh. Geol. Mijnb. Genootsch.v. Nederland en Kol. Geol. Serie 6: 43-148 
Den Berger, L.G. 1927. Unterscheidung-smerkmale von rezenten und fossilen Dipterocapaceen Gattungen. Bulletin du Jardin Botanique de Buitenzorg Series 3: 495-498.

Desch, H.E. 1941. Dipterocarps timbers of the Malay peninsula. Malayan Forest Record No. 14.

Ilic, J. 1994. Wood anatomy of Dryobalanops Gaertner f. In Soerianegara, I. and R.H.M.J. Lemmens (eds.) Plant resources of South East Asia 5 (1) Timber trees: Major commercial timbers. Bogor: Prosea.

Jafarsidik, Y. and C. Anwar. 1987. The composition of mangrove forest of Kali Bedahan estuary Pamanukan, West Java related to seaward migration of the shoreline. Forest Research Bulletin 491: 4-41.

Krausel, R. 1926. ber einige Fossile H Izer aus Java. Leidsche Geol. Mededeel. Bd. 2: 1-8.

Krausel, R. 1922a. Fossile H Izer aus dem Tertiar von S dSumatra. Verh. Geol. Minb. Genootsch. V. Nederland en Kol., Geol. Serie 5: 231-294.

Krausel, R. 1922b. eber einen Fossilen Baumstammm von Bolang (Java). Ein Beitrag zur Kenntnis der fossilken flora Niederlandisch-Indiens. Versl. Afd. Natuurkunde Kon. Akad. Amsterdam 31.

Krausel, R. 1925. Der Stand Unserer Kenntnisse von der Tertiarflora Nederlandisch-Indien. Verh. Geol. Mijnb. Genootsh. V. Nederlland en Kol., Geol. Serie 8: 3129-342

Mandang, Y.I. and D. Martono. 1996. Wood fossil diversity in the west region of Java Island. Buletin Penelitian Hasil Hutan 14 (5): 192-203.
Prawira, R.S.A. 1976. Daftar Nama Pohon Jawa Madura (I): Jawa Barat. Laporan No. 214, Bogor. Lembaga Penelitian Hutan.

Rusmana, E., K. Suwitodirdjo and Suharsono. 1991. Geology of the Serang Quadrangle, Java: Explanatory Note and Geological Map. Bandung: Geological Research and Development Centre.

Schweitzer, J.H. 1958. Die Fossilen Dipterocarpaceen-Hölzer. Paleontographica B 104 (1-4): 1-66.

Sidiyasa, K., S. Sutomo, and R.S. Among Prawira. 1985. Structure and composition of lowland dipterocarp forest at Leuweng Sancang Nature Reserve, West Java. Forest Research Bulletin 471: $37-48$.

Srivastava, R. and N. Kagemori. 2001. Fossil wood of Dryobalanops from Pliocene deposit of Indonesia. Paleobotanist 50: 395-401.

Steenis, C.G.G.J. and S.A.F. Schippers-Lamerste. 1963. Concise Plant Geography of Java. In Backer, C.A. and R.C. Bakhuizen van der Brink. Flora of Java. Vol. II. Leiden: Rijksherbarium.

Sutisna, U. 1995. Analysis of vegetation composition at Yanlapa Nature Reserve, West Java. Forest Research Bulletin 571: 4567.

Wheeler, E.A. and P. Baas. 1991. A survey of the fossil record for dicotyledonous wood and its significance for evolutionary and ecological wood anatomy. IAWA Bulletin 12 (3): 275-332.

Yamada, I. 1975. Forest ecological studies of montane forest of Mt. Pangrango, West Java. I. Stratification and floristic composition of montane rain forest near Cibodas. Tonan Ajia Kenkyu 13(3): 402-426. 